\title{
Realism in Chitra Banerjee Divakaruni’s Arranged Marriage
}

\author{
Jasmine Fernandez, \\ Guest Faculty, Department of Humanities, CUSAT, Kerala.
}

\begin{abstract}
Chitra Banerjee Divakaruni is an award winning author, born in Calcutta, who spent the first nineteen years of her life in India. Divakaruni has won a readership for her poetry and fiction of immigrant life in the US which takes us into the female psyche and interruption through real forms of violence. Her spatial and geographical boundary is always the immigrants to the US. Divakaruni's works captures the female caught in the closed up Indian society who once crossing the Lakshman Rekha of marriage is deemed to be a passive victim suffering in silence both at home land and abroad. Her woman character becomes the centre for stories of dislocation- geographical and emotional, recollected narratives of mother and daughter and narratives of women who accept change.
\end{abstract}

\section{Introduction:}

Divakaruni is a much celebrated diaspora writer whose pre occupation is to deal with realism faced by the immigrant women and women in traditional Indian society, unlike the other writers. This is evident from her stories like The Bats, Clothes, Maid Servants story, ultrasound, Meeting Mrinal which has Calcutta as its geographical locus and Silver Pavement, A Perfect Life, Doors, Affairs which has the US as its geographical setting. Divakaruni, by painting the lives of the women in detail, points to the realities of life after marriage: most of these women who became dislocated both geographically and emotionally. They become institutions of passive suffering both in India and abroad alike. Marriage mostly undoes women, and they are brutalized and marginalized and becomes victims of a patriarchal society in India. For those abroad find themselves dissatisfied with their new lives because of the clash of the opposite cultures and the constant thought of being trapped in an atmosphere which they are not wholly ready to accept because of a sense of hypocrisy. As a feminist writer, she could see them as her neighbours and could sympathize with them in their little joys, sorrows, and could reveal the pretty selfishness and strong bond which dominates human life, the harsh realities faced by Indian women once they are married, and the brutality and inescapability from the patriarchal society's glaring and determining their rights as human. Even if the women wanted to escape the institution of marriage, she has no choice but to stay as a passive sufferer.

On close analysis of her Indian women abroad a trace of the trapped feelings of these women becomes evident which sometimes even destroy their 'self' too. Culture for them can never be equated with the more free and open western women. A sense of guilt predominates once they abandon their native culture. The real life dilemma and troubles of the immigrants are captured in vivid detail.

As a realist Divakaruni copied their customs, institutions, traditions, beliefs, superstitions, myths etc. into her stories. It is worth keeping in mind what realism means. To adapt, M.H. Abrams's definitions of realistic fiction, "represents life and the social world as it seems to the common reader, evolving the sense that its characters might in fact exist and such things might well happen".

The story "The Bats" is an excellent example of this realism. The mother is a typical Indian woman stuck up in the web of social stigma and prejudice that she finds it difficult to shed off the past and move towards a renewed life and vision away from the patriarchal society. The young child, a girl (daughter) is caught between an abusive and cruel father and a helpless mother. The young girl for then realized that her "mother cried a lot" and faced the trauma each night of disturbed sleep and sees the sound of her mother crying "the sound of her weeping would be all around me, pressing in wave upon wave, until I would no longer tell where it was coming from". Divakaruni vividly portrays the child's incapacity to understand her mother's agony initially and why her mother had to share her narrow child's bed. The child's gradual understanding and apprehension of her father figure who never gives any affections for her. "I didn't see him much. I heard him, through shouts that shook the walls of my bedroom like they were paper, the sounds of falling dishes". For this child well acquainted with the draconian father it is not very hard to discern the foggy and painful life of her mother, she understands the cause of her mother's blotch that appeared after nights of falling dishes and sounds. So at the mere suggestion of her mother to escape to their grandpa uncle's house brings a thrill into her heart. Though this escapade was a short lived, it was a life of unending happiness.

"Grandpa Uncle soon became my best friend. All day I would follow him around as he went about his job which was taking care of the Zamindar's orchard. He taught me all the names of trees - mango, lichee, kul - 
and let me taste the first ripe fruits. He pointed out hares and squirrels and girgits that hid in the grass, their shiny greenish bodies pulsing in the sun. On his off days he took me fishing and taught me how to hold the rod tight." (7) But soon these days of bliss was gone as it was only a temporary refuge. Mother unable to bear "the stares and whispers of the women, down in the market place" decides to return to her tormenting husband. The realization that conventional society has no place for a woman who walks out of the Lakshman Rekha(marriage), the marital bond to which she is bound. The patriarchal society's customs and culture is such a way that "it is a one way cross over" and there is "no coming back" for a married woman. The mother is in a dilemma and finds she has no offer of help or relief. This is the case of most divorced women in Indian society.

The writer draws a parallel to the life of the wife and the bats. Both are hunted for being in the wrong places. Spinsters and divorced women are the most affected when they tend to walk their own paths. Just like the bats which simply do not decrease in number. Grandpa says "I guess they just don't realize what's happening. They don't realize that by flying somewhere else they'll be safe. Or maybe, they do, but there's something that keeps putting them back here." (8)

The story "Ultrasound" presents a realistic portrayal of the treatment which an expecting mother meets after knowing about the arrival of a girl child. The mother-to-be Runu is castigated for not giving birth to a male child. Runu's friend Anju invites her to America in order to give her reprieve from her ill-fated life. Yet thoughts about the possible future of her friend thwart her. "Had I taken all that away from her by my misplaced American notion of feminism and justice." (227) The patriarchal society's injustice meted out to women and girl children is poignantly pointed out by Divakaruni. Female foeticide is quite a reality in many a village in India. Though various social reforms and awareness programmes are not quite uncommon in India not much has ever changed .General statistics stands true to it. The ill-treatment and rude attitude of female infanticide is questioned.

"Perfect Life" is the story of Meera and Richard who were in a live in relationship. But on the sudden appearance of six year old boy in a rose garden, upsurges her motherly instinct. She names the boy Krishna and takes care of him. Her life completely changes. "Mother love, that tidal wave swept everything else away. Friendship romantic fulfillment evens the need for sex" (98-99). The disappearance of the child from the adoption centre actually jeopardizes her life. The once appeared "civilized, as much in control as perfect."(77) life crumbles down. She marries Richard on the condition that she is never burden with biological maternity and also to get herself back.

The story "Doors" is a classic example of the contrast between the cultures of India and the West. Indians are usually brought up in large joint families and there is not so much as called private and personal space unlike the West with its individual culture where there is a distinct space between private and public life. Deepak who is from India marries Preeti who is settled in America. Preeti is more of a private person and finds it hard to adjust when Deepak's younger sibling comes to stay to do his higher education in America. But hospitality is quite different in both societies which results in a great clash between the couple. Preeti always like her doors to be closed and needs a private space which she is not ready to share even with her husband.

In another story "Clothes" the husband of the narrator, Sunita dies and she is faced with the decision of staying in America or going back to India to live with her in laws. Sunita calls widows who are serving in laws in India "doves with cut of wings". Divakaruni deals with a variety of issues in the book, including racism, interracial relationship, economic disparity, abortion and divorce. She says stories are inspired by her imagination and the experience of others. (Mehta 4)

In the story "The Word Love", the heroine starts living with a man. Love is a magical word and it is difficult to define it easily. She accepted westernization in totality that she started to live with her boy friend outside the institution of marriage. But here past (her culture) thwarts her. She recollects how her mother had taken pains to bring her up after her father's death. Mother - daughter relationship is quite different in Indian culture. She regrets for hiding the relationship with her mother, however she finally faces the wrath of losing her mother on confessing the truth.. Her boyfriend on knowing her relationship says "it was never me, was it, never love. It was always you and her, her and you".(70) Thus parental love makes her take a decision to live alone. The writer here poignantly the realism present in Indian culture where the society is a closed one and it is very different to accept relationship outside the institution of marriage any such relationship, often result in conventional violence, social exclusions from the society and even abandonment from parents and relatives.

\section{Conclusion}

The arranged marriage was a collection of realistic stories dealing with the personal and social difficulties of Indian women living in the USA and Calcutta. In one of her interviews she says "First, I believe a writer should draw fresh boundaries and I wanted to try something new"

In one of the reviews by the San Francisco chronicle it says "beautifully told stories of transformed lives. Both liberated and trapped by cultural changes on both sides of the ocean, these women, struggle fiercely to carve out an identity of their own". (San Francisco Chronicle). 
In Arranged Marriage, Divakaruni "beautifully tells stories about the immigrant brides who are struggling to carve out and identity of their own." (Holf 1). Realistic setting of the geographical area Calcutta and USA, enlivens the characters and bring the city with its colours dust and rivers, the old folk tales and customs all pass before the readers like a motion picture. The joy of marriage bells and the anxious family all bring life to the stories Arranged Marriage.

\section{Works Cited}

[1] Mehta, Julie. “Arranging One's Life”. (1996) web. <http:www.metroactive.com/papers/metro/san10.03.96/books-9640.html>

[2] Holf, Patricia "Women feel tug of two cultures".SanFrancisco Chronicle (1August1995) E5.

[3] Divakaruni, Chitra Bannerjee. Arranged Marriage. Black Swan, Great Britain.1997.Print

[4] Bishop,P.(2009).AnalyticaPsycholgy \&German ClassicalAesthetic;Goethe,Schiller,and YoungVolume2.The Constellation of the Self.London:Routledge,pg171.Print.

[5] Abrams,M.,H., A Glossary of Literary terms. USA: Michael Rosenberg. Print. 